\title{
Investigate the Long-Run Trade-Off between Inflation and Unemployment in Egypt
}

\author{
Mahmoud Abdelaziz Touny ${ }^{1,2}$ \\ ${ }^{1}$ Faculty of Commerce and Business Administration, Helwan University, Egypt \\ ${ }^{2}$ Faculty of Applied Studies and Community Service, Dammam University, Saudi Arabia \\ Correspondence: Mahmoud Abdelaziz Touny, Faculty of Applied Studies and Community Service, Dammam \\ University, Al-Khobar 31952, P.O. Box 40287, Kingdom of Saudi Arabia. Tel: 966-53-353-3903. E-mail: \\ tony_mah@yahoo.com or mabdelaal@ud.edu.sa
}

\author{
Received: May 3, 2013 \\ Accepted: May 29, 2013 \\ Online Published: June 20, 2013 \\ doi:10.5539/ijef.v5n7p115 \\ URL: http://dx.doi.org/10.5539/ijef.v5n7p115
}

\begin{abstract}
The main objective of this study is to investigate the long run trade-off between unemployment and inflation in Egypt through the period (1974-2011) using Johansen-Juselius (1990) cointegration test and Vector Error Correction Model (VECM). Results of ADF test indicate that both series are cointegrated of order one I(1). Add to that, the outcomes of cointegration analysis confirm a positive relationship between changes in inflation rate and unemployment gap in the long run, which is consistent with "Locus Critique" where a policy of inflation would fail to reduce the unemployment rate in the long run, because workers would eventually adjust their expectations of inflation. Results of the ECM have illustrated that the error-correction term is negative and significant with an adjustment coefficient of - 0.280 , pointing out that changes in inflation rate adjust to its equilibrium level in the long run with $28 \%$ of the adjustment taking place within the first year.
\end{abstract}

Keywords: unemployment, Inflation, expectations-augmented Phillips curve, unemployment gap, Johansen-Juselius cointegration analysis, Vector Error Correction Model

\section{Introduction}

Unemployment has become progressively one of the major problems facing both developing and developed countries. With the spread of the financial crisis that started in the United States of America and transferred into the real economy worldwide, the economic growth decreased, which has led to a high rate of unemployment. Economic stagnation after October 2008 led to an increase in the number of unemployed to 20 million to become unemployed around the world (Tunali, 2010). On the other hand, inflation phenomenon has shown remarkable changes from the mid-eighties of the last century. Inflation has become less persistent, less responsive to supply side shocks (Ali, 2011).

The trade-off between inflation and unemployment has become one of the most important tools that central banks take into account when designing and implementing the monetary policy. Therefore, Phillips curve implies significant implications for policy makers. One of the major objectives of central banks is to stabilize prices through controlling inflation. Central banks tend to develop their monetary policy in such a way that enables them to maintain inflation at the lowest possible level. However, if there is a negative relationship between inflation and unemployment, central banks can keep low inflation rates, but this implies consequently to accept high rates of unemployment (Furuoka, 2007).

As a result, considerable research has been devoted to study the relationship between unemployment and inflation. The issue of the trade-off between inflation and unemployment however is still much debated among researchers. The combination of low inflation and low unemployment levels in the United States in the late 1990s makes some people to believe that there is no longer a trade-off between these two variables, or maybe it did not exist at all. Although there are several studies studying the Phillips curve, there is still a shortage of empirical analysis that tests the interaction between inflation and unemployment in developing countries as the majority of research has been concentrated mainly on the developed countries (Mankiw, 2001).

Egypt has recently decided to adopt price stability as an explicit monetary policy objective. Since June 2005, the Central Bank of Egypt has implemented some steps to develop its monetary policy in order to controlling 
inflationary pressures in the medium term (Khodeir, 2012). Therefore, it is important to study the trade-off between inflation and unemployment in Egypt in order to give some implications to monetary policy makers to be taken into account.

The main purpose of this study is to reveal the true relationship between inflation and unemployment in Egypt. Therefore, the main research point of the present study is to test whether there is a trade-off relationship between unemployment and inflation in Egypt or not. The null hypothesis is that there is no relationship between unemployment and inflation. The study tries to investigate the short-run and long-run effects of this relationship through the period (1974-2011) by estimating the expectations-augmented Phillips curve. In this study, cointegration technique proposed by Johansen and Juselius (1990) is used to reveal the long term relationship, while the Error Correction Model is utilized to investigate the dynamic short-run interaction between inflation and unemployment. The outcomes of this study may help policy makers to achieve conflicting objectives of price stability and full employment in Egypt.

The paper is structured as follows. Section II discusses the theoretical and empirical literature concerning the trade-off between inflation and unemployment. Section III, displays methodology used in this study and analyzes some data about inflation and unemployment levels in Egypt during the study period. Using econometric techniques, section IV explores the trade-off between inflation and unemployment. Finally, section IIV provides a short conclusion and policy implications.

\section{Theoretical and Empirical Literature about Inflation-Unemployment Tradeoff}

The Phillips curve represents the main widely concept dealing with the trade-off between inflation and unemployment. The original formulation of the Phillips curve is defined as an inverse relationship between the unemployment rate and the rate of increase in money wages:

$$
w=f(U), f^{\prime}(U)<0
$$

where $(w)$ points to the rate of growth of money wage $(\mathrm{W})$, and $(\mathrm{U})$ is the unemployment rate.

This relationship was tested empirically by Phillips (1958) using data from the United Kingdom through the period $(1861$ - 1957). The results of his study demonstrated that there is a negative correlation between unemployment and the growth rate of nominal wages (Gottschalk, 2005).

The general form of the original Phillips curve can be written as:

$$
g_{w}=-\varepsilon\left(U-U_{N R}\right)
$$

where:

$g_{w}:$ the rate of wage inflation.

$\varepsilon$ : parameter that measures the responsiveness of wages to unemployment.

$\mathrm{U}$ : unemployment rate.

$\mathrm{U}_{\mathrm{NR}}$ : the natural rate of unemployment.

Equation (2) states that wages are falling $\left(g_{w}<0\right)$ when the unemployment rate exceeds the natural rate (U $>$ $\left.\mathrm{U}_{\mathrm{NR}}\right)$, rising $\left(g_{w}>0\right)$ when the unemployment rate is less than the natural rate $\left(\mathrm{U}<\mathrm{U}_{\mathrm{NR}}\right)$ and are stable $\left(g_{w}=0\right)$ when the unemployment rate is equal to the natural rate $\left(\mathrm{U}=\mathrm{U}_{\mathrm{NR}}\right)$.

As it is stated before, the original Phillips curve relates wage inflation to the unemployment rate. Later on, in the early 1960s, the curve was modified by Paul Samuelson and Robert Solow presenting it as an inverse relation of inflation rate $(\pi)$ and unemployment $(\mathrm{U})$. This relationship can be represented by the following equation:

$$
\pi=-\varepsilon\left(U-U_{N R}\right)
$$

where $\pi$ is the inflation rate and $\varepsilon$ is a parameter that measures now the responsiveness of prices to unemployment.

In USA, Samuelson \& Solow (1960) demonstrated that there is a negative relationship between inflation and unemployment. This result was supported by Solow (1970) and Gordon (1971) where their findings revealed an inverse relationship between inflation and unemployment. (Zaman, Khan, Ahmad, \& Ikram, 2011).

During 1970s, The Monetarists illustrated that the traditional Phillips curve was miss-specified and provided an alternative concept which is called the expectations-augmented Phillips curve and supported by stagflation in the 1970s. Another criticism of the Phillips curve which is known as the "Lucas critique" was provided by Lucas (1976) who argued that if workers make correct expectations of future inflation, they will ask for higher wages. As a result, there could be a positive correlation between inflation and unemployment rate (Gottschalk, 2005 \& 
Zaman et al, 2011). Friedman (1968) produced the so-called 'expectations-augmented Phillips curve' given by:

$$
\pi=\pi^{e}-\varepsilon\left(U-U_{N R}\right)
$$

where $\pi^{\mathrm{e}}$ is the expected or trend inflation rate. Equation (4) states that inflation, $\pi$, will decline relative to the previous trend, $\pi^{\mathrm{e}}$, if the actual unemployment rate, $\mathrm{U}$, exceeds the natural rate, $\mathrm{U}_{\mathrm{NR}}$ (Pallis, 2006).

Friedman assumed that expectations are formed adaptively, $\pi^{\mathrm{e}}=\pi_{\mathrm{t}-1}$, meaning that workers couldn't correctly expect increasing of current prices as they form their expectations of future inflation depending on the dominant levels of inflation in the previous period. As a result of that, real wages will decline due to the unexpected increase in inflation, and in turn firms will increase their demand for labor and consequently decrease unemployment rate. This conclusion supports the inverse relationship between inflation and unemployment as indicated by the traditional Phillips curve. The difference between the traditional Phillips curve and the monetarist viewpoint is that, in the monetarists argue that the direction turns from aggregate demand through unpredicted inflation to the unemployment level, whereas the Keynesian analysis shows that the direction runs from aggregate demand through the unemployment level to nominal wages and inflation. This means that the expectations-augmented Phillips curve confirms the other direction of causality between inflation and unemployment (Gottschalk, 2005).

Another important difference between the traditional and the expectations-augmented Phillips curve related to the long-run characteristics of the Philips curve. The traditional Philips curve confirms the long run relationship between inflation and unemployment, but this is not valid in the expectations-augmented Phillips curve. In the long run, expected inflation is assumed to be equal to actual inflation and thus they drop out of equation (4). As a result inflation rate will be stable in the long run and there will be no relationship between unemployment and inflation in that case. (The vertical long-run Phillips curve) (Gottschalk, 2005).

Friedman (1968) illustrated that there is a level of unemployment below which inflation rises, which is called the natural rate of unemployment. Therefore, the direction of inflation (up or down) depends on the size unemployment gap (the difference between unemployment rate and the natural rate of unemployment). If unemployment gap is negative, there is excess demand for labor which puts pressures on real wages to rise. On the other hand, if unemployment gap is positive, excess labor supply will be the result and therefore real wages tend to decline. Therefore, we could expect higher inflationary pressures or less rapidly falling inflation in the former case than in the latter (Pallis, 2006).

This situation is included in equation (4) by modifying it into the following:

$$
\pi_{t}=\pi_{t}^{e}-\varepsilon\left(U_{t}-U_{N R}\right)-\gamma\left(U_{t}-U_{t-1}\right)
$$

where $\gamma$ reflects the extent to which changing unemployment $\left(U_{t}-U_{t-1}\right)$ affects inflation. The larger is $\gamma$, the more important is the effect of changing unemployment on the inflation rate. Equation (5) shows that current inflation depends on three things; on the expected inflation rate, on the unemployment gap, and on the speed by which unemployment changes. This equation is called the 'expectations augmented and change-in-unemployment extended Phillips curve'.

Equation (5) is very useful for policy decisions because it suggests that there is a concrete trade-off between reduction in unemployment and disinflation. The more rapid the reduction in unemployment rate, the less disinflation is achieved at each unemployment rate level. Even at the cases where the unemployment rate is very high, the inflation rate falls little and thus the economy is moving too rapidly out of the recession (Pallis, 2006).

From the previous analysis, we can conclude that there is a change of the relationship between inflation and unemployment over time. In particular, through 1980s, the Phillips curve was of interest to researchers during this period, but remained of concerns by policy makers. During the nineties, an interest of studying Phillips curve revived again by researchers and became the place of debate and controversy because the economies stabilized and the greatest world economies observed stable inflation. Results of recent research indicated that the Phillips curve relationship is still valid during economic downturns, even through the last recession (Zaman et al, 2011).

In an empirical study, Llaudes (2005) studied the role of long-term unemployment in the determination of prices and wages in a set of OECD countries and found that unemployment duration matters for inflation dynamics, and that the long-term unemployment had a smaller effect on inflation. The results also showed that in those countries where long-term unemployment was high, the long-term unemployment played a little role in the setting of prices and wages.

Karanassou, Sala, \& Snower (2005) re-examined the interactive relationship between inflation and 
unemployment by estimating dynamic multi-equation models. They used two models; one for the U.S. data and the other for the the European Union. Their results showed that the proper Phillips curve is flat and the existence of inflation-unemployment tradeoff was due to the slope of the Phillips curve in the long run. Pallis (2006) investigated the relationship between inflation and unemployment in the 10 new European Union countries for the period from 1994 to 2005. For comparison purposes, the Phillips curves for the EU-15 and the EU-25 were also estimated. The paper concluded that in almost all countries the interaction between the price inflation rate and the unemployment level took place in a rather longer time period, reaching in some cases the lag of year four. To investigate the relationship between unemployment volatility and inflation, Warne \& Vredin (2006) applied VAR models using monthly data of inflation and unemployment from the U.S., UK, and Sweden. The results of this study confirmed that an increase in conservativeness of the central bank was related to the degree of changes in unemployment levels.

Using the Johansen co-integration methods and Vector Error Correction Model (VECM) analysis, Furuoka (2007) investigated the correlation between unemployment levels and inflation rate in Malaysia through 1973 to 2004. Findings of this paper indicated to the existence of a negative long-run relationship between inflation and unemployment. Add to that, the results of VECM showed that the direction of the relationship in the short-run was from unemployment to inflation, which supported the existence of the Phillips curve. Karanassou, Sala, \& Snower (2008) examined the influence of the US frictional growth on the interaction between inflation and unemployment using semi-annual dataset of the period 1960-2005. Results of the GMM and SVAR models jointly determined the major forces of inflation and unemployment and pointed to a high interaction between inflation and unemployment in the long term.

Tunali (2010) investigated the causes of unemployment in Turkey utilizing the co-integration technique and the Error Correction Model (ECM) depending on quarterly data ranging from 2000 to 2008. The empirical results of this study referred to a negative, but weak, relationship between unemployment and inflation. Add to that, this research provided evidence of the hysteresis effect in Turkish economy where lagging levels of unemployment affect subsequently levels of unemployment.

Using vector auto-regression, simultaneous equations, and chain reactions, Karanassou \& Sala (2010) provided another support of the long term trade-off between inflation and unemployment in the United Sates. The results of their estimated models confirmed that the slope of the US Phillips curve is away from vertical, even in the long term, which means that both real and nominal sides of the economy are overlapped. Kitov \& Kitov (2011) provided an empirical model to check the impact of inflation and unemployment reactions to changes in the labor force in Switzerland using data from 1965 to 2010. Overall, findings of this paper established that there exist long term equilibrium relations between the rate of labor force change and inflation rate. In Pakistan, Zaman et al (2011) utilized a data set of 35 years (1975-2009) to study the Phillips Curve approach. Non-parametric estimates of the Non-Accelerating Inflation Rate of Unemployment (NAIRU) are calculated, and the results indicated that there is a casual and permanent relationship between inflation and unemployment in the long term, while this relationship was transient in the short run. More recently, Haq et al (2012) analyzed the long term interactions between unemployment and inflation in Pakistan from 1974 to 2010, using Johansen co-integration test and Vector Error Correction Model (VECM). The results of this study provided further support for the existence of a long term relationship between unemployment and inflation. On the other hand, the outcomes of VECM revealed a positive and significant correlation between inflation and unemployment either in the long term or the short term.

Generally, the empirical results of the trade-off between inflation and unemployment have shown mixed results. It can be concluded from the previous discussion that there is uncertain relationship between inflation and unemployment, which may be positive or negative according to the behavior of different economies in certain period. Therefore, the hypothesis of the Phillips curve has been open to more discussion and policy makers may be worried about the short term implications of the price stabilization policy as it may result in a negative effect on the unemployment levels. However, in the long term, the unemployment rate would settle around the equilibrium level of unemployment. In this case, policy makers could procedure their monetary policy without considering the adverse effects on unemployment.

It is clear the importance to recognize the relationship between inflation and unemployment when determining the macroeconomic policies for an economy. Despite the availability of several studies that examined the Phillips curve hypothesis, there is still a shortage of applied studies that investigate this hypothesis under developing countries where the majority of research has concentrated on the developed nations. The outcomes of this study may help policy makers to formulate better policies that can achieve their objectives of price stability and full employment in Egypt. Moreover, this study aims to re-examine empirically the theoretical interactions between 
inflation and unemployment in Egypt.

\section{Research Methodology and Data Analysis}

This study investigates the long run relationship between unemployment and inflation depending on the formulation provided by Blanchard (2005). The Phillips curve can be expressed in the following format:

$$
\pi_{t}-\pi_{t}^{e}=\beta_{2}\left(U_{t}-U_{N R}\right)+\varepsilon_{t}
$$

Where $\pi_{\mathrm{t}}$ : The actual inflation rate at time $\mathrm{t}$.

$\pi_{\mathrm{t}}^{\mathrm{e}}$ : The expected inflation rate at time $\mathrm{t}$.

$\mathrm{U}_{\mathrm{t}}$ : The actual unemployment rate prevailing at time $\mathrm{t}$.

$\mathrm{U}_{\mathrm{NR}}$ : The natural rate of unemployment at time $\mathrm{t}$.

$\varepsilon_{\mathrm{t}}$ : The stochastic error term.

Since $\pi_{t}^{e}$ is not directly observable, a simplifying assumption that $\pi_{t}^{e}=\pi_{t-1}$ is applied, which means that the inflation rate expected that year is the inflation rate that prevailed in the previous year. The Phillips relationship given in equation (6) is known as the modified Phillips curve or the expectation-augmented Phillips curve.

To estimate $\mathrm{U}_{\mathrm{NR}}$, the model can be transformed to be:

$$
\begin{aligned}
\pi_{t}-\pi_{t-1} & =\beta_{2}\left(U_{t}-U_{N R}\right)+\varepsilon_{t} \\
& =\beta_{1}+\beta_{2} U_{t}+\varepsilon_{t}
\end{aligned}
$$

Where $\beta_{1}=-\beta_{2} \mathrm{U}_{\mathrm{NR}}$ which means that $\mathrm{U}_{\mathrm{NR}}=-\frac{\beta_{1}}{\beta_{2}}$

The inflation rate is measured by the annual change in the Consumer Price Index (CPI) (2000 was the base year). Data of the CPI and the unemployment level was collected from Central Agency for Public Mobilization and Statistics (CAPMAS), Egypt and covers annual observations for the period (1974-2011).

In the first stage, this study employs the Ordinary Least Squares (OLS) regression model of equation (7) to estimate the natural rate of unemployment. In the second stage, the estimated value of $U_{\mathrm{NR}}$ is substituted in model (6) to investigate the long-run relationship between inflation and unemployment using the expectation-augmented Phillips curve. To examine whether a time series has a unit root or not, an Augmented Dickey-Fuller (ADF) test has been used. If variables are stationary of the same order, then the Johansen cointegration test will be used to check the long-run movement of the variables.

The procedure to test for stationarity in the levels of variables starts with the most unrestricted model (a drift and time trend are included). For the ADF test, the number of lagged first difference should be determined to add in the test regression. In this study, the proper lags are specified according to Schwarz Information Criterion (SIC).

If the ADF test shows that the series is not stationary in level but stationary in first differences, then the series is said to be integrated of order one I (1). If a linear combination of two or more series is stationary, and they have the same order of integration, then it is said that these series are cointegrated. In addition, the estimation of error correction models (ECM) in one step can be made after conducting the cointegration test.

This study applies Johansen-Juselius cointegration test. The Johansen cointegration test is based on maximum likelihood estimation of the Vector Autoregressive (VAR) model of order (p). To determine the number of vectors cointegration, Johansen $(1988,1991) \&$ Johansen and Juselius (1990) proposed two test statistics; the trace statistics and the maximum eigenvalue statistic. Johansen and Juselius's method tests three hypotheses about the cointegrating relationships:

- There are no cointegrating relationships; the regression is spurious.

- There is at most one cointegrating relationship.

- There are at most two cointegrating relationships.

The trace test is based on the $\log$-likelihood ratio and is conducted sequentially for $r=0,1, \ldots, p-1$ :

$$
\lambda_{\text {trace }}(\mathrm{r})=-\mathrm{T} \sum_{\mathrm{i}=\mathrm{r}+1}^{\mathrm{p}} \ln \left(1-\hat{\lambda}_{\mathrm{i}}\right)
$$

Where $\left(\lambda_{r+1}, \ldots ., \lambda_{p}\right)$ represents the least eignvectors (p-r).

The null hypothesis of this statistic test is that there are at most (r) cointegrating vectors against the alternative of (p) cointegrating vectors.

The maximum eigenvalue statistic test is based on the log-likelihood ratio that takes this form: 


$$
\lambda_{\max }(\mathrm{r}, \mathrm{r}+1)=-\mathrm{T} \ln \left(1-\hat{\lambda}_{\mathrm{r}+1}\right)
$$

The null hypothesis of this test is that the cointegration rank is equal to (r) against the alternative hypothesis that the cointegration rank is equal to $(\mathrm{r}+1)$.

There is not much reason to prefer one test over the other. Fortunately, they frequently lead to the same conclusion. If none of the three hypotheses are rejected, one must worry that the regression is spurious. If the first hypothesis is only rejected, this means that there is only one cointegrating relationship $(r=1)$. If the first and second hypotheses are rejected, this indicates that there are two cointegrating relationships $(\mathrm{r}=2)$.

Once the number of cointegrating vectors has been determined, we can return to the model formulation, re-estimate the model under the restriction that there are (r) cointegrating vectors. After that, the Vector Error Correction Model (VECM) will be run with only stationary variables:

$$
\Delta\left(\pi_{\mathrm{t}}-\pi_{\mathrm{t}-1}\right)=\alpha+\sum_{\mathrm{i}=1}^{\mathrm{n}} \beta_{\mathrm{i}} \Delta \mathrm{UG}_{\mathrm{t}-\mathrm{i}}+\sum_{\mathrm{i}=1}^{\mathrm{n}} \delta_{\mathrm{i}} \Delta\left(\pi_{\mathrm{t}}-\pi_{\mathrm{t}-1}\right)_{\mathrm{t}-\mathrm{i}}+\gamma \mathrm{ECT}_{\mathrm{t}-1}+\varepsilon_{\mathrm{t}}
$$

Where UG: unemployment gap $\left(\mathrm{U}_{\mathrm{t}}-\mathrm{U}_{\mathrm{NR}}\right)$

\section{$\mathrm{ECT}_{\mathrm{t}-1}$ : the lagged error correction term}

The lag length is determined by minimising the Akaike information criterion (AIC).

Figure (1) traces the unemployment rate movements with the inflation rate in Egypt during the period of study. In general, unemployment in Egypt has been one of the major problems since 1980s. Until the mid-1970s, the dominant activities of investment in Egypt were in public sector and import substitution industries represented the main source of growth and employment. During that period, unemployment levels were relatively low (about $2-3 \%$ ) due to the employment policy of the Egyptian government which guaranteed employment for most entrants to the labor force. Since 1990, the Egyptian economy has witnessed an increasing trend of unemployment levels and remained significantly high, in the range of 8-11\% (Hassan \& Sassanpour, 2008).

The economic reform program implemented in Egypt through 1990s had a positive effect on economic growth levels, but expansion of employment opportunities was limited during that period, and the youth unemployment problem began to appear dramatically. At the beginning of the 2000s, the problem of unemployment worsened, especially with the wave of economic recession suffered by the Egyptian economy during that period, and this figure continued until the end of 2000s (see Fig. (1)). The annual growth rate (on average) of the workforce in Egypt was about $3.2 \%$ during 2000 s. The labor force is characterized by the dominance of men (more than three fourth of the total) due to the low rate of female participation (see Fig. (2)). According to a survey of the labor force conducted by CAPMAS in 2005, about $92 \%$ of all those unemployed were under the age of 30 . Almost half of all the unemployed were in the 20-25 age group (Hassan \& Sassanpour, 2008).

On the other hand, inflation rate witnessed an upward trend until the beginning of 1990s where inflation rate started to decline to reach about $1.55 \%$ in 2000 , and began to increase after that (see Fig. (1)). The Egyptian economy through 1980s, especially the second half of the 1980s, suffered from macroeconomic imbalances reflected in decelerated economic growth and high inflation rate. On the other hand, expansionary financial policies through 1980s helped to maintain a high level of domestic demand which, in turn, exerted strong pressures on prices. As a result of these economic conditions, many internal and external imbalances have emerged at the economic level, which led a steady increase in the aggregate demand that was not consistent with the aggregate supply levels. (Kheir El-Din \& El-Dersh 1992; Ali, 2011). Such factors have increased the rates of inflation markedly to record the highest levels during the study period in 1986, where inflation had risen to nearly $24 \%$.

At the beginning of the 1990s, Egypt adopted the first stage of the Economic Reform and Structural Adjustment Program (ERSAP) whose primary target was to achieve the highest standards of price stability and control on the increases in domestic liquidity. As a result of this stabilization and in addition to the contractionary demand policies that followed in the first stage of the ERSAP, the inflation rate had a declining path. The inflation rate was between 19.66 percent in 1991 and 1.66 percent in 1999. (see Fig. (1)).

During 2000s, Inflation in Egypt seemed to have a gradually increasing trend with several elevated inflation (double digit). The inflation rates increased significantly during this period and reached about 18 percent in 2003 and 2008. The first spike in 2003 mainly reflected the effect of the huge devaluation of the Egyptian pound in 2003, where the Egyptian government in January 2003 turned towards the liberalization of the Egyptian currency, and abandoned the managed peg regime. The second spike in 2008 was caused by the increase of world commodity prices (Moriyama, 2011). 


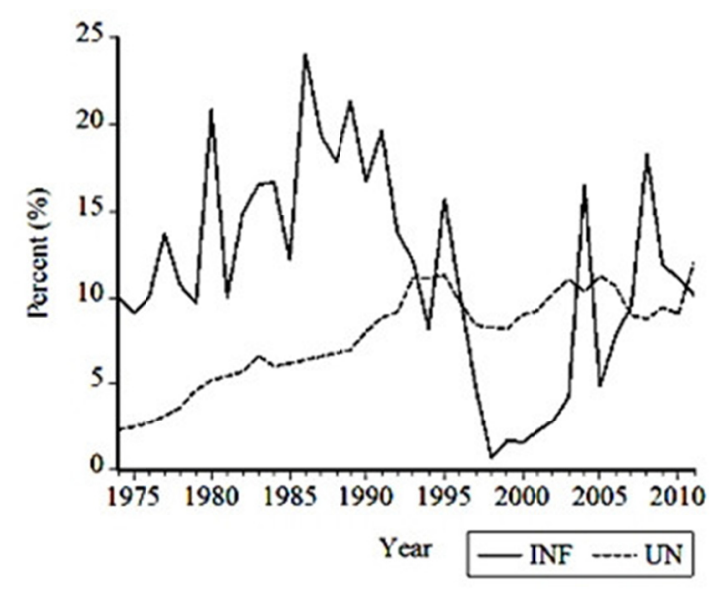

Figure 1. Inflation and unemployment rates in Egypt (1974-2011)

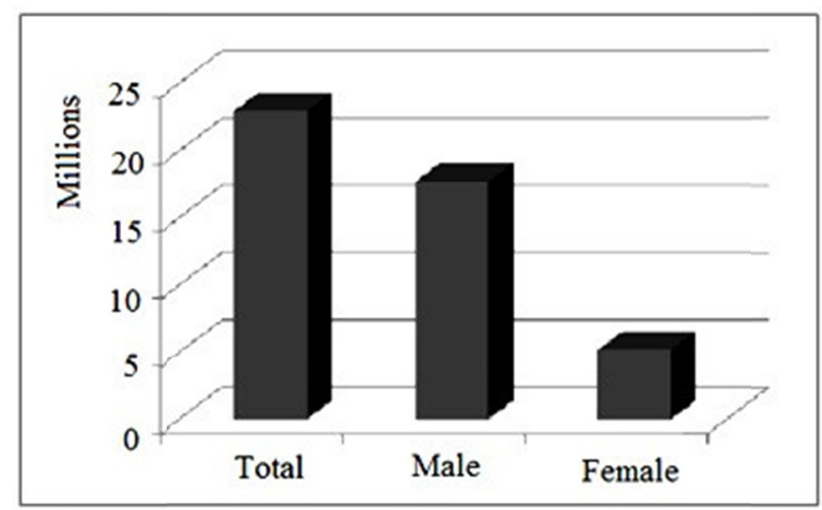

Figure 2. Average labor force in Egypt (2001-2011)

Source: Done by the researcher depending on data collected from CAPMAS.

\section{The Empirical Results}

\subsection{Unit Root Test}

The first step of the empirical analysis is to estimate the natural rate of unemployment $\left(U_{N R}\right)$. The $U_{N R}$ is estimated from the regression of equation (7) and the estimated regression equation is:

$$
\left(\pi_{t} \widehat{-\pi_{t-1}}\right)=-4.361+1.427 U_{t}
$$

which means that $U_{\mathrm{NR}}=-\frac{\beta_{1}}{\beta_{2}}=-\frac{-4.361}{1427}=3.056$

Thus, the unemployment gap (UG) is calculated by $\left(\mathrm{U}-\mathrm{U}_{\mathrm{NR}}\right)$. After that, the ADF root test was applied to check the stationarity of the variables. The null hypothesis is that the series has a unit root (non-stationary). The results of ADF test are shown in Table 1. It is obvious from the results of ADF test that both series are not stationary at level, but stationary at first difference. This means that the two series are cointegrated of order one I(1).

Table 1. Results of Augmented Dickey-Fuller (ADF) Unit Root Test

\begin{tabular}{lllll}
\hline Variables & Test specification & Constant & Constant and trend & None \\
\hline$\pi_{\mathrm{t}}-\pi_{\mathrm{t}-1}$ & Level & $-3.04^{*}$ & -3.34 & -0.73 \\
& $1^{\text {st }}$ Difference & $-9.76^{* *}$ & $-9.64^{* *}$ & $-9.91^{* *}$ \\
UG & Level & -1.42 & -2.15 & 0.85 \\
& $1^{\text {st }}$ Difference & $-4.31^{* *}$ & $-4.17^{*}$ & $-3.97^{* *}$ \\
\hline
\end{tabular}

Notes: * indicates rejection of the null hypothesis of non-stationary at $5 \%, * *$ indicates rejection of the null hypothesis of non-stationary at $1 \%$. 


\subsection{Johansen's Cointegration Test}

Cointegration test is only sensible in the case of non-stationary series, integrated of the same order. As the previous analysis reveals that both variables are non-stationary and integrated of order (1), then Cointegration test using the common methodology of Johansen and Juseliues (1990) is applied which allows the mutual impact between the variables under the study.

Tables (2) and (3) show the results of Johansen cointegration test between changes in inflation rate and unemployment gap variables. The results of both trace and maximum eigenvalue test statistics point out that there is at least one co-integration vector between $\Delta\left(\pi_{t}-\pi_{t-1}\right)$ and $\Delta U G$. Values of trace statistics and maximum Eigenvalue statistics are greater than their critical values at five percent. In more details, since the calculated value of the trace test (22.89) is more than the critical value (15.49) at 5\% level of significance, it is possible to reject the null hypothesis that there is no cointegrated vector. In contrast, since the calculated value of the trace test (2.74) is less than the critical value of the test (3.84) at 5\% level of significance, the null hypothesis that there is at most one cointegrated vector can't be rejected. The results of Maximum Eigenvalue test provide similar results of trace test that there is at most one cointegrated vector. This means that the variables of changes in inflation rates and unemployment gap are co-integrated which confirms the existence of a long run equilibrium relationship between them. As a result, the ECM is estimated to reveal the short and long run interactions between inflation and unemployment.

Table 2. Results of Co-integration test (Trace test)

\begin{tabular}{lllll}
\hline No. of CE(s) & Trace Statistic & 0.05 Critical Value & Eigenvalue & Prob.** \\
\hline None $*$ & 22.89 & 15.49 & 0.438 & 0.003 \\
At most 1 & 2.74 & 3.84 & 0.075 & 0.098 \\
\hline
\end{tabular}

Notes: * denotes rejection of the null hypothesis at the 0.05 level, **MacKinnon-Haug-Michelis (1999) p-values.

Table 3. Results of Co-integration test (Maximum Eigenvalue test)

\begin{tabular}{lllll}
\hline No. of CE(s) & Max Eigen Statistic & 0.05 Critical Value & Eigenvalue & Prob.** \\
\hline None $*$ & 20.15 & 14.26 & 0.438 & 0.005 \\
At most 1 & 2.74 & 3.84 & 0.075 & 0.098 \\
\hline
\end{tabular}

Notes: * denotes rejection of the null hypothesis at the 0.05 level, **MacKinnon-Haug-Michelis (1999) p-values.

\subsection{Vector Error Correction Model (VECM)}

The previous results of cointegration analysis refer to the existence of a long run equilibrium relationship between the changes in inflation rate and unemployment gap, but it doesn't give any information about the direction of the causality between them. By specifying the long run relationship between variables in an error correction model, the short run, as well as the long run effects of all right hand side variables in equation, are estimated in one step. The adjustment process may take a number of periods and thus the equation of the ECM should have lagged variables. It is important to include the appropriate number of lags. The appropriate number of lags (5) is determined by Akaike AIC statistics where the appropriate lags is associated with the lowest value of AIC.

The normalized cointegration equation reveals that unemployment gap has a positive effect on the changes in inflation rate. The UG coefficient is (1.819) and is significant at $5 \%$, implying that a one percent increase in unemployment gap while others keep constant contributes $1.82 \%$ increase in the changes in inflation rate. This result confirms "Locus Critique" which implies a positive correlation between unemployment and inflation rate. It argues that if workers anticipate expected inflation then they would ask for high wages, and then high inflation may be accompanied by high unemployment. This result indicates that inflation would fail to reduce the unemployment rate in the long run, because workers would eventually adjust their expectations of inflation.

Table 4. Normalized cointegration vector

\begin{tabular}{lll}
\hline$\left(\pi_{\mathrm{t}}-\pi_{\mathrm{t}-1}\right)$ & Constant & $\mathrm{UG}$ \\
\hline 1.000 & 9.645 & 1.819 \\
Standard error & & $(0.873)$ \\
t-stat. & & 2.084 \\
\hline
\end{tabular}


Table 5 summarizes the results of the ECM. The error correction term (ECT) describes the short-run dynamics or adjustments of the cointegrated variables towards their equilibrium values. It is obvious that the coefficient of ECT is negative and statistically significant at $5 \%$. This result indicates that there is a long-run relationship between inflation and unemployment gap. The error-correction term is negative and significant with an adjustment coefficient of -0.280 , indicating that changes in inflation rate adjust to its long-run equilibrium level with $28 \%$ of the adjustment taking place within the first year.

These Findings provide important implications for policy makers to achieve their objectives of price stability and full employment in Egypt. As shown from the previous discussion, the results do not support any short-run trade-off between inflation and unemployment, while there is a positive relationship between them in the long term. Moreover, it is clear that the unemployment rate will settle around its long term equilibrium level. Therefore, policy makers could adopt the proper monetary policy required to reduce inflationary pressures without fear of its adverse impacts on unemployment rates.

The explanatory variables explain well over 70 percent of the variations in changes in inflation rate as indicated by adjusted R-squared. In addition, the probability of the F-Statistic suggests that the model has a very good fit.

Table 5. Results of Error Correction Model (ECM)

\begin{tabular}{llll} 
Dependent variable: $\mathrm{D}\left(\pi_{\mathrm{t}}-\pi_{\mathrm{t}-1}\right)$ & \multicolumn{3}{l}{} \\
\hline Variables & Coef. & t-stat. & P-value \\
\hline $\mathrm{ECT}$ & -0.280 & -1.940 & 0.042 \\
$\mathrm{D}\left(\pi_{\mathrm{t}}-\pi_{\mathrm{t}-1}(-1)\right)$ & -01.242 & -3.764 & 0.001 \\
$\mathrm{D}\left(\pi_{\mathrm{t}}-\pi_{\mathrm{t}-1}(-2)\right)$ & -1.462 & -3.495 & 0.002 \\
$\mathrm{D}\left(\pi_{\mathrm{t}}-\pi_{\mathrm{t}-1}(-3)\right)$ & -1.328 & -2.918 & 0.009 \\
$\mathrm{D}\left(\pi_{\mathrm{t}}-\pi_{\mathrm{t}-1}(-4)\right)$ & -0.714 & -1.881 & 0.075 \\
$\mathrm{D}\left(\pi_{\mathrm{t}}-\pi_{\mathrm{t}-1}(-5)\right)$ & -0.315 & -1.485 & 0.154 \\
$\mathrm{D}(\mathrm{UNG}(-1))$ & 0.208 & 0.145 & 0.886 \\
$\mathrm{D}(\mathrm{UG}(-2))$ & 0.494 & 0.358 & 0.724 \\
$\mathrm{D}(\mathrm{UG}(-3))$ & 0.777 & 0.543 & 0.594 \\
$\mathrm{D}(\mathrm{UG}(-4))$ & -0.601 & -0.420 & 0.679 \\
$\mathrm{D}(\mathrm{UG}(-5))$ & -2.871 & -1.872 & 0.081 \\
Constant & -2.349 & -1.081 & 0.293 \\
\hline R-squared & 0.816 & & \\
Adj. R-squared & 0.700 & & \\
F-statistic & 7.034 & $(\mathrm{p}$-value 0.001$)$ & \\
Log likelihood & -92.461 & & \\
Akaike AIC & 6.591 & & \\
\hline
\end{tabular}

The coefficient of the lag variables in ECM reveals the short run effects. Wald test is used to test the jointly effect of lag variables on the dependent variable. The Wald test is applied for each group of independent lag variables. Results of Wald test in table (6) indicate that the lag variables of $D\left(\pi_{t}-\pi_{t-1}\right)$ jointly influence the changes in inflation rate in the short-run, whereas lags of unemployment gap seem to have jointly insignificant effect on changes in inflation rate.

Table 6. Results of Waled test

\begin{tabular}{lll}
\hline Hypothesis & Chi Square & P-Value \\
\hline $\mathrm{H}_{0}: \delta_{1}=\delta_{2}=\delta_{3}=\delta_{4}=\delta_{5}=0$ & 17.185 & 0.004 \\
$\mathrm{H}_{0}: \beta_{1}=\beta_{2}=\beta_{3}=\beta_{4}=\beta_{5}=0$ & 4.405 & 0.493 \\
\hline
\end{tabular}

To check the normal distribution of the residuals, Histogram-Normality test is conducted and Jarque-Bera statistics is 0.944 ( $\mathrm{p}$-value 0.624 ) which indicates that the residuals are normally distributed. Also, LM test of serial correlation is conducted to check if the ECM has any serial correlation. The results of Breusch-Godfrey serial correlation LM test confirm that there is no serial correlation in the model. Finally, results of White Heteroscedasticity test show that the model is homoscedasticity. From the previous results, it is concluded that the model is well fitted, and thus the results of the ECM model can be accepted. 
Table 7. Results of serial correlation and Heteroscedasticity tests

\begin{tabular}{lll}
\hline Test & F-statistic & Obs. R-square \\
\hline Breusch-Godfrey LM test & 0.102 & 0.247 \\
& $(0.902)$ & $(0.852)$ \\
White Heteroscedasticity test & 1.277 & 26.049 \\
& $(0.392)$ & $(0.351)$ \\
\hline
\end{tabular}

Note: Value in parentheses refers to P-value.

\section{Summary and Conclusions}

The relationship between inflation and unemployment has changed over time. Empirical findings have shown mixed results, which indicate that interaction between inflation and unemployment is uncertain. The main objective of this study is to investigate the long run trade-off between unemployment and inflation in Egypt through the period (1974-2011) using Johansen-Juselius (1990) cointegration test and Vector Error Correction Model (VECM). Results of ADF test indicate that both series are cointegrated of order one I(1). For cointegration analysis, the results of both trace and maximum eigenvalue test statistics point out that there is at least one cointegration vector between variables, which confirm the long-run relationship between changes in inflation rate and unemployment gap over the above mentioned period in Egypt. The normalized cointegration equation reveals that unemployment gap has a long-run positive effect on the changes in inflation rate, which is consistent with "Lucas Critique" where a policy of inflation would fail to reduce the unemployment rate in the long run, because workers would eventually adjust their expectations of inflation. The outcomes of the ECM have illustrated that the error-correction term is negative and significant with an adjustment coefficient of -0.280 , indicating that changes in inflation rate settle to its long term equilibrium level with $28 \%$ of the adjustment taking place within the first year. These findings provide important implications for policy makers as they could implement their monetary policy to cope inflationary pressures without fear of its adverse impacts on unemployment rates.

\section{References}

Ali, H. (2011). Inflation Dynamics: The Case of Egypt. MPRA Paper 36331, University Library of Munich, Germany.

Blanchard, O. (2005). Macroeconomics (4th ed.). Prentice Hall, Englewood Cliffs, N.J.

Engle, R., \& Granger, C. (1987). Co-integration and Error Correction: Representation, Estimation and Testing. Econometrica, 55(2), 251-276. http://dx.doi.org/10.2307/1913236

Friedman, M. (1968). The Role of Monetary Policy. American Economic Review, 58, 1-17.

Furuoka, F. (2007). Does the "Phillips Curve" Really Exist? New Empirical Evidence from Malaysia. Economics Bulletin, 5(16), 1-14.

Gordon, R. J. (1971). Price in 1970: The Horizontal Phillips Curve. Brookings Papers on Economic Activities, 3, 449-458.

Gottschalk, J. (2005). Monetary Policy and the German Unemployment Problem in Macroeconomic Models: Theory and Evidence. Berlin, New York: Springer.

Haq, I., Khan, S., Khan, A., \& Ahmed, E. (2012). Phillips Curve or Locus Critique: Time Series Evidence from Pakistan. Journal of Economics and Behavioral Studies, 4(4), 190-193.

Hassan, M., \& Sassanpour, C. (2008). Labor market pressures in Egypt: Why is the unemployment rate stubbornly high? Journal of Development and Economic Policies, 10(2).

Johansen, S. (1988). Statistical analysis of cointegration vectors. Journal of Economic Dynamics and Control, Elsevier, 12(2-3), 231-254. http://dx.doi.org/10.1016/0165-1889(88)90041-3

Johansen, S. (1991). Estimation and Hypothesis Testing of Cointegrated Vectors in Gaussian VAR Models. Econometrica, 59(6), 1551-1580. http://dx.doi.org/10.2307/2938278

Johansen, S., \& Juselius, K. (1990). Maximum Likelihood Estimation and Inference on Cointegration with application to the Demand for Money. Oxford Bulletin of Economics and Statistics, 52, 169-210. http://dx.doi.org/10.1111/j.1468-0084.1990.mp52002003.x

Karanassou, M., \& Sala, H. (2010). The US inflation-unemployment trade-off revisited: New evidence for $\begin{array}{llllll}\text { policy-making. } & \text { Journal } & \text { of } & \text { Policy } & \text { Modeling, } & 32(6),\end{array}$ 
http://dx.doi.org/10.1016/j.jpolmod.2010.08.004

Karanassou, M., Sala, H., \& Snower, D. (2005). A Reappraisal of the Inflation-Unemployment Tradeoff. European Journal of Political Economy, 21(1), 1-32. http://dx.doi.org/10.1016/j.ejpoleco.2004.02.003

Karanassou, M., Sala, H., \& Snower, D. (2008). The Evolution of Inflation and Unemployment: Explaining the $\begin{array}{lllll}\text { Roaring Nineties. Australian } & \text { Economic }\end{array}$ http://dx.doi.org/10.1111/j.1467-8454.2008.00353.x

Kheir El-Din, H., \& El-Dersh, A. (1992). Foreign Trade Policy of Egypt, 1986-91. In S. El-Naggar (Ed.), Foreign and Intratrade Policies of the Arab Countries. IMF, Washington.

Khodeir, A. (2012). Towards inflation targeting in Egypt: The relationship between exchange rate and inflation. South African Journal of Economic and Management Sciences (Online), 15(3), 325-332.

Kitov, O., \& Kitov, I. (2011). Inflation and unemployment in Switzerland: from 1970 to 2050. MPRA Paper 28887, University Library of Munich, Germany.

Llaudes, R. (2005). The Phillips curve and long-term unemployment. Working Paper Series, 441, European Central Bank.

Lucas, R. (1976). Econometric Policy Evaluation: A Critique. Carnegie-Rochester Conference Series on Public Policy, 1, 19-46. http://dx.doi.org/10.1016/S0167-2231(76)80003-6

Mankiw, N. (2001). The Inexorable And Mysterious Tradeoff Between Inflation And Unemployment. Economic Journal, 111(471), 45-61. http://dx.doi.org/10.1111/1468-0297.00619

Moriyama, K. (2011). Inflation Inertia in Egypt and its Policy Implications. IMF Working Papers, No. 11/160, $1-26$.

Pallis, D. (2006). The Trade-Off between Inflation and Unemployment in the New European Union Member-States. International Research Journal of Finance and Economics, 1, 80-88.

Phillips, A. (1958). The Relationship between Unemployment and the Rate of Change of Money Wage Rates in the United Kingdom. Economica, 25, 258-299. http://dx.doi.org/10.1111/j.1468-0335.1958.tb00003.x

Samuelson, P., \& Solow, R. (1960). Analytical Aspect of Anti-inflation Policy. American Economic Review, 50, 177-194.

Sargent, J. (2002). Towards a New Economy? Recent Inflation and Unemployment in the United Kingdom. National Institute Economic Review, 181(1), 69-86. http://dx.doi.org/10.1177/002795010218100110

Solow, R. (1970). Discussion of RJ Gordon's Recent Acceleration of Inflation and its Lessons for the Future. Brookings Papers on Economic Activities, 1, 42-46.

Tunali, H. (2010). The Analysis of Unemployment in Turkey: Some Empirical Evidence Using Co-integration Test. European Journal of Social Sciences, 18, 18-38.

Warne, A., \& Vredin, A. (2006). Unemployment and Inflation Regimes. Studies in Non-Linear Dynamics and Econometrics, 10(2). http://dx.doi.org/10.2202/1558-3708.1280

Zaman, K., Khan, M., Ahmad, M., \& Ikram, W. (2011). Inflation, Unemployment and the NAIRU in Pakistan (1975-2009). International Journal of Economics and Finance, 3(1), 245-254.

\section{Copyrights}

Copyright for this article is retained by the author(s), with first publication rights granted to the journal.

This is an open-access article distributed under the terms and conditions of the Creative Commons Attribution license (http://creativecommons.org/licenses/by/3.0/). 